\title{
PERAN DAN TANGGUNG JAWAB STAF SEKOLAH DALAM BIMBINGAN DAN KONSELING BAGI SISWA
}

\author{
Syamsul Hadi \\ Sekolah Tinggi Agama Islam (STAI) Al-Amin, Indonesia \\ syamsulhadialamin@gmail.com
}

\begin{abstract}
Abstrak
Kajian ini adalah telaah mengenai peran dan tanggung jawab Staf Sekolah dalam pelaksanaan bimbingan dan konseling di sekolah. Kajian ini adalah kajian pustaka. Hasil dari kajian ini mengungkap bahwa Staf Sekolah memainkan peranan penting dalam kegiatan bimbingan dan konseling di sekolah. Peran tersebut mencakup peran sebagai informator, organisator, motivator, director, inisiator, transmitter, fasilitator, mediator, dan evaluator. Peran tersebut tidak dapat berjalan sendiri-sendiri, namun merupakan sebuah sistem yang saling melengkapi dalam kegiatan bimbingan dan konseling di sekolah.
\end{abstract}

Kata Kunci: staf sekolah; bimbingan karir; konseling

\section{PENDAHULUAN}

Undang-undang Sistem Pendidikan Nasional no. 20 tahun 2003 pasal 3 dinyatakan bahwa Pendidikan Nasional berfungsi mengembangkan kemampuan dan membentuk watak serta peradaban bangsa yang bermartabat dalam rangka mencerdaskan kehidupan bangsa, bertujuan untuk berkembangnya potensi peserta didik agar menjadi manusia yang beriman dan bertakwa kepada Tuhan Yang Maha Esa, berakhlak mulia, sehat, berilmu, cakap, kreatif, mandiri, dan menjadi warga negara yang demokratis serta bertanggung jawab.

Sejalan dengan tujuan pendidikan nasional maka dirumuskan tujuan pendidikan dasar yakni memberi bekal kemampuan dasar kepada siswa untuk mengembangkan kehidupannya sebagai pribadi, anggota masyarakat, warga negara dan anggota umat manusia serta mempersiapkan siswa untuk mengikuti pendidikan menengah (Depdikbud, 1990). 
Pendidikan dasar merupakan pondasi untuk pendidikan selanjutnya dan pendidikan nasional. Untuk itu aset suatu bangsa tidak hanya terletak pada sumber daya alam yang melimpah, tetapi terletak pada sumber daya alam yang berkualitas. Sumber daya alam yang berkualitas adalah sumber daya manusia, maka diperlukan peningkatan sumber daya manusia Indonesia sebagai kekayaan negara yang kekal dan sebagai investasi untuk mencapai kemajuan bangsa.

Bimbingan konseling adalah salah satu komponen yang penting dalam proses pendidikan sebagai suatu sistem. Hal ini sesuai dengan apa yang dikemukakan bahwa proses pendidikan adalah proses interaksi antara masukan alat dan masukan mentah. Masukan mentah adalah peserta didik, sedangkankan masukan alat adalah tujuan pendidikan, kerangka, tujuan dan materi kurikulum, fasilitas dan media pendidikan, system administrasi dan supervisi pendidikan, sistem penyampaian, tenaga pengajar, sistem evaluasi serta bimbingan konseling (Tim Pengembangan MKDK IKIP Semarang, 1990).

Bimbingan merupakan bantuan kepada individu dalam menghadapi persoalan-persoalan yang dapat timbul dalam hidupnya. Bantuan semacam itu sangat tepat jika diberikan di sekolah, supaya setiap siswa lebih berkembang ke arah yang semaksimal mungkin. Dengan demikian bimbingan menjadi bidang layanan khusus dalam keseluruhan kegiatan pendidikan sekolah yang ditangani oleh tenaga-tenaga ahli dalam bidang tersebut.

Di Sekolah, kegiatan Bimbingan Konseling tidak diberikan oleh Guru Pembimbing secara khusus seperti di jenjang pendidikan SMP dan SMA. Staf Sekolah harus menjalankan tugasnya secara menyeluruh, baik tugas menyampaikan semua materi pelajaran (kecuali Agama dan Penjaskes) dan memberikan layanan bimbingan konseling kepada semua siswa tanpa terkecuali.

Dalam konteks pemberian layanan bimbingan konseling, Prayitno mengatakan bahwa pemberian layanan bimbingan konseling meliputi layanan orientasi, informasi, penempatan dan penyaluran, pembelajaran, 
konseling perorangan, bimbingan kelompok, dan konseling kelompok (Amti, 1997).

Staf Sekolah harus melaksanakan ketujuh layanan bimbingan konseling tersebut agar setiap permasalahan yang dihadapi siswa dapat diantisipasi sedini mungkin sehingga tidak menggangu jalannya proses pembelajaran. Dengan demikian siswa dapat mencapai prestasi belajar secara optimal tanpa mengalami hambatan dan permasalahan pembelajaran yang cukup berarti.

Realitas di lapangan, khususnya di Sekolah Dasar menunjukkan bahwa Staf Sekolah dalam pelaksanaan bimbingan konseling belum dapat dilakukan secara optimal mengingat tugas dan tanggung jawab Staf Sekolah yang sarat akan beban sehingga tugas memberikan layanan bimbingan konseling kurang membawa dampak positif bagi peningkatan prestasi belajar siswa.

Dalam Pedoman Kurikulum Berbasis Kompetensi bidang Bimbingan Konseling tersirat bahwa suatu sistem layanan bimbingan dan konseling berbasis kompetensi tidak mungkin akan tercipta dan tercapai dengan baik apabila tidak memiliki sistem pengelolaan yang bermutu. Artinya, hal itu perlu dilakukan secara jelas, sistematis, dan terarah. Untuk itu diperlukan guru pembimbing yang profesional dalam mengelola kegiatan Bimbingan Konseling berbasis kompetensi di sekolah dasar.

Berangkat dari kerangka fikir tersebut di atas, penulis tergerak untuk melakukan telaah mengenai peran dan tanggung jawab Staf Sekolah dalam pelaksanaan Bimbingan Konseling di Sekolah. Persoalan mendasar yang hendak dikaji lebih jauh melalui tulisan ini adalah bagaimana peran dan tangung jawab staf sekolah dalam Bimbingan Karir (BK)?

\section{METODE}

Tulisan ini merupakan hasil telaah pustaka untuk mengungkap bentuk peran staf sekolah dalam melaksanakan kegiatan bimbingan konseling di sekolah. Berbagai literatur yang terkait dikaji dengan seksama dan 
dibandingkan antara yang satu dengan yang lainnya untuk mendapatkan jabaran tentang: (1) hakikat bimbingan dan konsling, (2) urgensi bimbingan dan konseling di sekolah, (3) fungsi bimbingan dan konseling di sekolah, (4) prinsip-prinsip bimbingan konseling di sekolah, (5) bentuk kegiatan bimbingan konseling dalam Kurikulum Berbasis Kompetensi, (6) dan peran staf sekolah dalam kegiatan bimbingan konseling di sekolah.

\section{HASIL DAN PEMBAHASAN}

Berdasarkan analisis berbagai litaratur, bagian ini akan menjabarkan 6 aspeks terkait bimbingan dan konseling di sekolah, yaitu (1) hakikat bimbingan dan konsling, (2) urgensi bimbingan dan konseling di sekolah, (3) fungsi bimbingan dan konseling di sekolah, (4) prinsip-prinsip bimbingan konseling di sekolah, (5) bentuk kegiatan bimbingan konseling dalam Kurikulum Berbasis Kompetensi, (6) dan peran staf sekolah dalam kegiatan bimbingan konseling di sekolah.

\section{Hakikat Bimbingan dan Konsling}

M. Surya berpendapat bahwa bimbingan adalah suatu proses pemberian atau layanan bantuan yang terus menerus dan sistematis dari pembimbing kepada yang dibimbing agar tercapai perkembangan yang optimal dan penyesuaian diri dengan lingkungan (Surya, 1988).

Bimbingan ialah penolong individu agar dapat mengenal dirinya dan supaya individu itu dapat mengenal serta dapat memecahkan masalah-masalah yang dihadapi di dalam kehidupannya (Hamalik, 2000).

Bimbingan adalah suatu proses yang terus-menerus untuk membantu perkembangan individu dalam rangka mengembangkan kemampuannya secara maksimal untuk memperoleh manfaat yang sebesar-besarnya, baik bagi dirinya maupun bagi masyarakat (Tim Pengembangan MKDK IKIP Semarang, 1990).

Dari beberapa pendapat di atas dapat ditarik sebuah inti sari bahwa bimbingan dalam penelitian ini merupakan suatu bentuk bantuan yang diberikan kepada individu agar dapat mengembangkan 
kemampuannya seoptimal mungkin, dan membantu siswa agar memahami dirinya (self understanding), menerima dirinya (self acceptance), mengarahkan dirinya (self direction), dan merealisasikan dirinya (self realization).

Konseling adalah proses pemberian yang dilakukan melalui wawancara konseling oleh seorang ahli kepada individu yang sedang mengalami suatu masalah yang bermuara pada teratasinya masalah yang dihadapi oleh klien (Amti, 1997).

Konseling merupakan upaya bantuan yang diberikan kepada seseorang supaya dia memperoleh konsep diri dan kepercayaan pada diri sendiri, untuk dimanfaatkan olehnya dan memperbaiki tingkah lakunya pada masa yang akan dating (Wibowo, 1986). Dari pengertin tersebut, dapat penulis sampaikan ciri-ciri pokok konseling, yaitu:

1) adanya bantuan dari seorang ahli,

2) proses pemberian bantuan dilakukan dengan wawancara konseling,

3) bantuan diberikan kepada individu yang mengalami masalah agar memperoleh konsep diri dan kepercayaan diri dalam mengatasi masalah guna memperbaiki tingkah lakunya di masa yang akan datang.

\section{Perlunya Bimbingan dan Konseling di sekolah}

Jika ditinjau secara mendalam, setidaknya ada tiga hal utama yang melatarbelangi perlunya bimbingan yakni tinjauan secara umum, sosio kultural dan aspek psikologis. Secara umum, latar belakang perlunya bimbingan berhubungan erat dengan pencapaian tujuan pendidikan nasional, yaitu: meningkatkan kualitas sumber daya manusia Indonesia yaitu manusia yang beriman dan bertaqwa terhadap Tuhan Yang Maha Esa, berbudi pekerti luhur, berkepribadian, berdisiplin, bekerja keras, tangguh, bertanggung jawab, mandiri, cerdas dan terampil serta sehat jasmani dan rohani.

Untuk mewujudkan tujuan tersebut sudah barang tentu perlu mengintegrasikan seluruh komponen yang ada dalam pendidikan, salah 
satunya komponen bimbingan. Bila dicermati dari sudut sosio kultural, yang melatar belakangi perlunya proses bimbingan adalah adanya perkembangan ilmu pengetahuan dan teknologi yang pesat sehingga berdampak disetiap dimensi kehidupan. Hal tersebut semakin diperparah dengan laju pertumbuhan penduduk yang tinggi, sementara laju lapangan pekerjaan relatif menetap.

Menurut Tim Pengembangan MKDK IKIP Semarang (1990), ada lima hal yang melatarbelakangi perlunya layanan bimbingan di sekolah yakni:

1) masalah perkembangan individu,

2) masalah perbedaan individual,

3) masalah kebutuhan individu,

4) masalah penyesuaian diri dan kelainan tingkah laku, dan

5) masalah belajar.

\section{Fungsi Bimbingan dan Konseling di sekolah}

Sugiyo menyatakan bahwa ada tiga fungsi bimbingan dan konseling, yaitu:

1) Fungsi penyaluran (distributif)

Fungsi penyaluran ialah fungsi bimbingan dalam membantu menyalurkan siswa-siswa dalam memilih program-program pendidikan yang ada di sekolah, memilih jurusan sekolah, memilih jenis sekolah sambungan ataupun lapangan kerja yang sesuai dengan bakat, minat, cita-cita dan ciri- ciri kepribadiannya. Di samping itu fungsi ini meliputi pula bantuan untuk memiliki kegiatan-kegiatan di sekolah antara lain membantu menempatkan anak dalam kelompok belajar, dan lain-lain.

2) Fungsi penyesuaian (adjustif)

Fungsi penyesuaian ialah fungsi bimbingan dalam membantu siswa untuk memperoleh penyesuaian pribadi yang sehat. Dalam berbagai teknik bimbingan khususnya dalam teknik konseling, siswa dibantu menghadapi dan memecahkan masalah-masalah dan kesulitan- 
kesulitannya. Fungsi ini juga membantu siswa dalam usaha mengembangkan dirinya secara optimal.

3) Fungsi adaptasi ( adaptif)

Fungsi adaptasi ialah fungsi bimbingan dalam rangka membantu staf sekolah khususnya guru dalam mengadaptasikan program pengajaran dengan ciri khusus dan kebutuhan pribadi siswa-siswa. Dalam fungsi ini pembimbing menyampaikan data tentang ciri-ciri, kebutuhan minat dan kemampuan serta kesulitan-kesulitan siswa kepada guru. Dengan data ini guru berusaha untuk merencanakan pengalaman belajar bagi para siswanya. Sehingga para siswa memperoleh pengalaman belajar yang sesuai dengan bakat, cita-cita, kebutuhan dan minat (Sugiyo, 1997).

\section{Prinsip-prinsip Bimbingan Konseling di Sekolah}

Prinsip merupakan paduan hasil kegiatan teoretik dan telaah lapangan yang digunakan sebagai pedoman pelaksanaan sesuatu yang dimaksudkan (Amti, 1997). Berikut ini prinsip-prinsip bimbingan konseling yang diramu dari sejumlah sumber, sebagai berikut:

a. Sikap dan tingkah laku seseorang sebagai pencerminan dari segala kejiwaannya adakah unik dan khas. Keunikan ini memberikan ciri atau merupakan aspek kepribadian seseorang. Prinsip bimbingan adalah memperhatikan keunikan, sikap dan tingkah laku seseorang, dalam memberikan layanan perlu menggunakan caracara yang sesuai atau tepat.

b. Tiap individu mempunyai perbedaan serta mempunyai berbagai kebutuhan. Oleh karenanya dalam memberikan bimbingan agar dapat efektif perlu memilih teknik-teknik yang sesuai dengan perbedaan dan berbagai kebutuhan individu.

c. Bimbingan pada prinsipnya diarahkan pada suatu bantuan yang pada akhirnya orang yang dibantu mampu menghadapi dan mengatasi kesulitannya sendiri. 
d. Dalam suatu proses bimbingan orang yang dibimbing harus aktif , mempunyai bayak inisiatif. Sehingga proses bimbingan pada prinsipnya berpusat pada orang yang dibimbing.

e. Prinsip referal atau pelimpahan dalam bimbingan perlu dilakukan. Ini terjadi apabila ternyata masalah yang timbul tidak dapat diselesaikan oleh sekolah (petugas bimbingan). Untuk menangani masalah tersebut perlu diserahkan kepada petugas atau lembaga lain yang lebih ahli.

f. Pada tahap awal dalam bimbingan pada prinsipnya dimulai dengan kegiatan identifikasi kebutuhan dan kesulitan-kesulitan yang dialami individu yang dibimbing.

g. Proses bimbingan pada prinsipnya dilaksanakan secara fleksibel sesuai dengan kebutuhan yang dibimbing serta kondisi lingkungan masyarakatnya.

h. Program bimbingan dan konseling di sekolah harus sejalan dengan program pendidikan pada sekolah yang bersangkutan. Hal ini merupakan keharusan karena usaha bimbingan mempunyai peran untuk memperlancar jalannya proses pendidikan dalam mencapai tujuan pendidikan.

i. Dalam pelaksanaan program bimbingan dan konseling di sekolah hendaklah dipimpin oleh seorang petugas yang benar-benar memiliki keahlian dalam bidang bimbingan. Di samping itu ia mempunyai kesanggupan bekerja sama dengan petugas-petugas lain yang terlibat.

j. Program bimbingan dan konseling di sekolah hendaknya senantiasa diadakan penilaian secara teratur. Maksud penilaian ini untuk mengetahui tingkat keberhasilan dan manfaat yang diperoleh dari pelaksanaan program bimbingan. Prinsip ini sebagai tahap evaluasi dalam layanan bimbingan konseling nampaknya masih sering dilupakan. Padahal sebenarnya tahap evaluasi sangat penting artinya, di samping untuk menilai tingkat 
keberhasilan juga untuk menyempurnakan program dan pelaksanaan bimbingan dan konseling.

\section{Kegiatan BK dalam Kurikulum Berbasis Kompetensi}

Berdasakan Pedoman Kurikulum Berbasis Kompetensi bidang Bimbingan Konseling dinyatakan bahwakerangka kerja layanan BK dikembangkan dalam suatu program BK yang dijabarkan dalam 4 (empat) kegiatan utama (Juntika, 2005), yaitu:

a. Layanan dasar bimbingan

Layanan dasar bimbingan adalah bimbingan yang bertujuan untuk membantu seluruh siswa mengembangkan perilaku efektif dan ketrampilan-ketrampilan hidup yang mengacu pada tugas-tugas perkembangan siswa.

b. Layanan responsif

Layanan responsif adalah layanan bimbingan yang bertujuan untuk membantu memenuhi kebutuhan yang dirasakan sangat penting oleh peserta didik saat ini. Layanan ini lebih bersifat preventik atau mungkin kuratif. Strategi yang digunakan adalah konseling individual, konseling kelompok, dan konsultasi. Isi layanan responsif adalah:

1) bidang pendidikan;

2) bidang belajar;

3) bidang sosial;

4) bidang pribadi;

5) bidang karir;

6) bidang tata tertib;

7) bidang narkotika dan perjudian;

8) bidang perilaku sosial, dan

9) bidang kehidupan lainnya.

c. Layanan perencanaan individual adalah layanan bimbingan yang membantu seluruh peserta didik dan mengimplementasikan rencanarencana pendidikan, karir,dan kehidupan sosial dan pribadinya. 
Tujuan utama dari layanan ini untuk membantu siswa memantau pertumbuhan dan memahami perkembangan sendiri.

d. Dukungan sistem, adalah kegiatan-kegiatan manajemen yang bertujuan memantapkan, memelihara dan meningkatkan progam bimbingan secara menyeluruh. Hal itu dilaksanakan melalui pengembangaan profesionalitas, hubungan masyarakat dan staf, konsultasi dengan guru, staf ahli/penasihat, masyarakat yang lebih luas, manajemen program, penelitian dan pengembangan.

e. Kegiatan utama layanan dasar bimbingan yang responsif dan mengandung perencanaan individual serta memiliki dukungan sistem dalam implementasinya didukung oleh beberapa jenis layanan BK, yakni:

1) layanan pengumpulan data,

2) layanan informasi,

3) layanan penempatan,

4) layanan konseling,

5) layanan referal/melimpahkan ke pihak lain, dan

6) layanan penilaian dan tindak lanjut.

\section{Peran Staf Sekolah dalam Kegiatan BK di Sekolah}

Implementasi kegiatan BK dalam pelaksanaan Kurikulum Berbasis Kompetensi sangat menentukan keberhasilan proses belajar-mengajar. Oleh karena itu peranan Staf Sekolah dalam pelaksanaan kegiatan BK sangat penting dalam rangka mengefektifkan pencapaian tujuan pembelajaran yang dirumuskan.

Sardiman (2001) menyatakan bahwa ada sembilan peran guru dalam kegiatan BK, yaitu:

a. Informator, guru diharapkan sebagai pelaksana cara mengajar informatif, laboratorium, studi lapangan, dan sumber informasi kegiatan akademik maupun umum.

b. Organisator, guru sebagai pengelola kegiatan akademik, silabus, jadwal pelajaran dan lain-lain. 
c. Motivator, guru harus mampu merangsang dan memberikan dorongan serta reinforcement untuk mendinamisasikan potensi siswa, menumbuhkan swadaya (aktivitas) dan daya cipta (kreativitas) sehingga akan terjadi dinamika di dalam proses belajar-mengajar.

d. Director, guru harus dapat membimbing dan mengarahkan kegiatan belajar siswa sesuai dengan tujuan yang dicita-citakan.

e. Inisiator, guru sebagai pencetus ide dalam proses belajar-mengajar.

f. Transmitter, guru bertindak selaku penyebar kebijaksanaan dalam pendidikan dan pengetahuan.

g. Fasilitator, guru akan memberikan fasilitas atau kemudahan dalam proses belajar-mengajar.

h. Mediator, guru sebagai penengah dalam kegiatan belajar siswa.

i. Evaluator, guru mempunyai otoritas untuk menilai prestasi anak didik dalam bidang akademik maupun tingkah laku sosialnya, sehingga dapat menentukan bagaimana anak didiknya berhasil atau tidak.

\section{KESIMPULAN}

Berdasarkan uraian di atas dapat disimpulkan bahwa Staf Sekolah dalam pelaksanaan Bimbingan Konseling di Sekolah memainkan peranan yang sangat penting. Sejalan diberlakukannya Kurikulum Berbasis Kompetensi, Staf Sekolah mempunyai peran yang sentral dalam kegiatan BK. Peran tersebut mencakupi peran sebagai informator, organisator, motivator, director, inisiator, transmitter, fasilitator, mediator, dan evaluator. Peran tersebut tidak dapat berjalan sendiri-sendiri, namun merupakan sebuah sistem yang saling melengkapi dalam kegiatan Bimbingan dan Konseling di Sekolah.

Mewujudkan Staf Sekolah dalam pelaksanaan kegiatan BK di Sekolah bukanlah hal yang mudah. Hal tersebut dikarenakan, di sekolah tidak memiliki Guru Pembimbing. Staf Sekolah memiliki tanggung jawab ganda, di samping mengajar juga membimbing. Oleh karena itu, Staf Sekolah hendaknya meningkatkan pengetahuan dan pemahaman tentang 
pelaksanaan kegiatan BK sehingga memiliki wawasan yang mendalam terhadap kegiatan-kegiatan BK di Sekolah.

\section{DAFTAR PUSTAKA}

Depdiknas. 2004. Pedoman Kurikulum Berbasis Kompetensi bidang

Bimbingan Konseling. Jakarta: Puskur Balitbang Depdiknas.

M. Surya. 1988. Pengantar Bimbingan dan Penyuluhan. Jakarta : UT.

Mungin Eddy Wibowo. 1986. Konseling di Sekolah Jilid I. FIP IKIP Semarang.

Nurihsan, Juntika. 2005. Manajemen Bimbingan Konseling di SD

Kurikulum 2004. Jakarta: Gramedia Widiasaraan Indonesia.

Oemar Hamalik. 2000. Psikologi Belajar dan Mengajar. Bandung: Sinar Baru Algensindo.

PP nomor 28 tahun 1990 tentang Pendidikan Dasar. Jakarta: Dedpikbud.

Prayitno Erman Amti. 1997. Dasar-dasar Bimbingan dan Konseling. Jakarta: Depdikbud.

Sardiman. 2001. Interaksi dan Motivasi Belajar-Mengajar. Jakarta: Raja Grafindo Persada.

Sugiyo, dkk. 1987. Bimbingan dan Konseling Sekolah. Semarang: FIP IKIP Semarang.

Tim Pengembangan MKDK IKIP Semarang. 1990. Bimbingan dan Konseling Sekolah. Semarang: IKIP Semarang Press.

UU Nomor 20 Tahun 2003 tentang Sistem Pendidikan Nasional. Jakarta: Tamita Jaya Utama.

Winkel, 1991, Bimbingan dan Konseling di Sekolah, Jakarta : Alfabeta, Ground 